\title{
Moraxella atlantae sp. nov. and Its Distinction from Moraxella phenylpyrouvica
}

\author{
K. BØVRE, J. E. FUGLESANG, N. HAGEN, E. JANTZEN, AND L. O. FRøHOLM \\ Department of Microbiology, University Hospital and Institute of Medical Biology, University of Troms $\phi$, \\ Troms $\phi$, Norway; Kaptein W. Wilhelmsen og Frues Bakteriologiske Institutt, \\ University of Oslo, Rikshospitalet, Oslo, Norway; and Methodology Department, National \\ Institute of Public Health, Oslo, Norway
}

\begin{abstract}
A homogeneous group of gram-negative, rod-shaped, and oxidase-positive bacterial strains, growing with small colonies, is described. In ordinary culturalbiochemical tests, the entity appeared most similar to Moraxella phenylpyrouvica, although it has so far been distinguished from that species by its simultaneous lack of urease and phenylalanine and tryptophan deaminase activities, inability to grow on solid medium at 4 to $10^{\circ} \mathrm{C}$, relative salt sensitivity, and different behaviour on bile-containing media. The fatty acid composition was very similar to that of $M$. phenylpyrouvica, but the organism was distinguishable from the latter in containing a fatty alcohol, $n$-octadecanol, and mannose. Its genetic affinity to $M$. phenylpyrouvica and other recognized Moraxella species appeared very low, but was detectable by transformation. The guanine plus cytosine content of its deoxyribonucleic acid was 46.0 to $47.5 \mathrm{~mol} \%$, which is 2.5 to $4.0 \%$ higher than in $M$. phenylpyrouvica. The entity is considered a new species of genus Moraxella, and the Moraxella atlantae is proposed.
\end{abstract}

The late Elizabeth O. King, Communicable Disease Center, Atlanta, Ga., provided us with a number of oxidase-positive, rod-shaped bacterial strains of unknown relation to Moraxella. On genetic and other bases, several of the strains were later allocated to three newly created species, Moraxella osloensis $(3,8), M$. phenylpyrouvica (9), and Kingella kingae (11, $16,18)$. The material received from King also contained a group of strains that was urease negative (named group 3 by her; see also reference 24), but was otherwise very similar to urease-positive strains later found to belong to $M$. phenylpyrouvica. Four strains of her group 3 and a similar strain isolated in Oslo were, in the present study, examined in detail and compared to $M$. phenylpyrouvica. Initially, the affinities of the strains were studied by genetic transformation and determination of deoxyribonucleic acid (DNA) base composition. Subsequently, the genetically defined groups were compared phenotypically.

\section{MATERIALS AND METHODS}

Bacterial strains. Four strains were received from the late Elizabeth O. King, Atlanta, Ga. Their CDC (Communicable Disease Center) numbers are A279, A1922, 5118, and 8330. Strain B19941/75 was received from Tone Skarpaas, National Institute of Public Health, Oslo, Norway. All strains had been isolated from human clinical material-four from blood and one (strain 8330) from spleen.
The following strains of $M$. phenylpyrouvica were included for comparison: 240, A390, 752/52, A1019= ATCC 23335, A1232, $2863=$ ATCC $23333=$ NCTC 10526 (type strain), $5542=$ ATCC $23334,9158,9413$, $11865 / 52=$ ATCC 19991, and ATCC 17950. Strain 240 was received from U. Berger, Hygiene-Institut der Universität, Heidelberg, Germany, and strain $11865 / 62$ was from S. D. Henriksen, Kaptein W. Wilhelmsen og Frues Bakteriologiske Institutt, University of Oslo, Norway. The other strains were included in the original description of $M$. phenylpyrouvica (9).

The genetic transformation experiments included strains of all known species of Moraxella, Kingella, Acinetobacter and several Neisseria species (see Tables 2 and 3 ). Their mutual genetic relations were studied previously (references of Tables 2 and 3 ).

Genetic transformation. The procedures of mutant selection, preparation of donor DNA, and quantitative transformation with streptomycin resistance as the genetic marker were the same as those used before (7). Resistant mutants were selected in a one-step procedure on blood agar plates at a concentration of $500 \mu \mathrm{g} / \mathrm{ml}$ of streptomycin. The DNA exposure was terminated after $20 \mathrm{~min}$ by deoxyribonuclease. Assay of transformants were performed at a streptomycin concentration of $50 \mu \mathrm{g} / \mathrm{ml}$, to insure uncritical conditions for phenotypic expression. In addition, the sensitive technique of long-term DNA exposure on plates during growth (7) was used when estimating genetic relationships between species or groups.

Determination of DNA base composition. DNA was prepared and its buoyant density in $\mathrm{CsCl}$ gradients was determined in an analytical ultracentri- 
fuge as previously described (5). The density was measured versus Escherichia coli K-12 DNA, considered traditionally to have the density $1.710 \mathrm{~g} / \mathrm{cm}^{3}$. The average DNA base composition, i.e., the moles percentage of guanine plus cytosine $(\mathrm{mol} \% \mathrm{G}+\mathrm{C})$, was calculated from the buoyant density, using the simplified formula mol\% $\mathrm{G}+\mathrm{C}=1,000(\rho-1.660)$, where $\rho=$ buoyant density in $\mathrm{g} / \mathrm{cm}^{3}$ (5). Two separate experiments were performed, including the strains A279, A1922, 5118, and two $M$. phenylpyrouvica controls of known DNA base composition (see Table 4). In experiment b, Table 4, the analytical ultracentrifugation was kindly performed by $\mathbf{M}$. Fiandt, McArdle Laboratory for Cancer Research, University of Wisconsin, Madison, Wis.

Cultural and associated procedures. The characterization was based on the methodology proposed as Minimal Standards for Description of New Taxa in the Genera Moraxella and Acinetobacter (10). Examination for poly- $\beta$-hydroxybutyrate inclusions was performed after $20 \mathrm{~h}$ of growth on $10 \%$ horse serum nutrient agar containing $0.5 \%$ DL- $\beta$-hydroxybutyrate, as well as from Hutner medium when growth occurred. Agar corrosion and colony spreading were generally studied on freshly prepared human blood agar plates (6) incubated in a humid atmosphere. Colonies were photographed in incident light, except when examining for twitching motility (15); in the latter case, cultures on tryptose blood agar base (Oxoid) were studied by transmitted light phasecontrast microscopy, using a long focal distance condensor and a dry objective. $\mathrm{H}_{2} \mathrm{~S}$ production was tested for on TSI medium. Salt tolerance was studied by growth at different concentrations of sodium chloride incorporated in blood agar medium, and bile salt stimulation and tolerance were studied after incorporation of bile salts (Oxoid, code L55) in plates of tryptose blood agar base (Oxoid). When not particularly mentioned, the incubation temperature was $33^{\circ} \mathrm{C}$.

Negative-stain electron microscopy. The negative-stain electron microscopy techniques were generally as described (6). Cells were scraped off blood agar plates after 11 and $24 \mathrm{~h}$ of growth (humid atmosphere) and suspended in $0.8 \%$ (wt/vol) sodium silicotungstate ( $\mathrm{pH} 7$ ). During microscopy, a long focal distance holder for increased contrast was used in some instances.

Gas chromatography of whole cells. Fatty acids and the alcohol 18:0alc (see Results) were identified and quantitated by cultural, chemical, and gas chromatographic procedures previously described (19, 21), with few modifications. Lyophilized bacterial cells $(10 \mathrm{mg}$ ) were treated with $2 \mathrm{~N} \mathrm{HCl}$ in anhydrous methanol. After centrifugation, components of the supernatants were derivatized by trifluoroacetic anhydride, and the fatty acid methyl esters (including fatty alcohol) were selectively extracted by hexane. The analyses were performed on a Hewlett-Packard 5830A gas chromatograph, equipped with a flame ionization detector. Two glass columns ( $2 \mathrm{~m}$ long, $2 \mathrm{~mm}$ inner diameter) were used, with either 10\% UCC-W982 (Hewlett-Packard) (unpolar) or $10 \%$ EGA (Supelco Inc.) (polar) on Gas-Chrom Q (100 to 120 mesh). Flow rate of carrier gas $\left(\mathrm{N}_{2}\right)$ was $20 \mathrm{ml} / \mathrm{min}$. The temperature programme for the unpolar column started at $120^{\circ} \mathrm{C}$ and was increased by 2 degrees per min up to $270^{\circ} \mathrm{C}$; for the polar column the temperature was increased from $140^{\circ}$ to $200^{\circ} \mathrm{C}$, by increments of 2 degrees per min, and then kept at $200^{\circ} \mathrm{C}$ for $20 \mathrm{~min}$. The amount of each component is given (see Table 6) as the percentage of the total fatty acid (plus alcohol) content as determined from analysis on the unpolar column.

Gas chromatographic monosaccharide analysis of

TABLE 1. Quantitative streptomycin resistance transformation ${ }^{a}$, showing intraspecies affinities between strains A279, A1922, 5118, 8330 and B19941/75

\begin{tabular}{|c|c|c|c|c|}
\hline Expt no. ${ }^{b}$ & Recipient strain & Donor strain & $\begin{array}{c}\text { Transformant yield } \\
(\mathrm{T} / \mathrm{E})^{\mathrm{c}}\end{array}$ & $\begin{array}{c}\text { Ratio of interstrain to autolo- } \\
\text { gous transformation }\end{array}$ \\
\hline 1 & $\mathrm{~A} 1922$ & $\begin{array}{l}\text { A1922 } \\
\text { A279 } \\
5118 \\
8330\end{array}$ & $\begin{array}{l}1.5 \times 10^{-2} \\
1.1 \times 10^{-2} \\
1.0 \times 10^{-2} \\
1.2 \times 10^{-2}\end{array}$ & $\begin{array}{l}7.3 \times 10^{-1} \\
6.7 \times 10^{-1} \\
8.0 \times 10^{-1}\end{array}$ \\
\hline 2 & 5118 & $\begin{array}{l}5118 \\
\text { A279 } \\
\text { A1922 }\end{array}$ & $\begin{array}{l}5.3 \times 10^{-4} \\
2.5 \times 10^{-4} \\
3.5 \times 10^{-4}\end{array}$ & $\begin{array}{l}4.7 \times 10^{-1} \\
6.6 \times 10^{-1}\end{array}$ \\
\hline 3 & 5118 & $\begin{array}{l}5118 \\
8330\end{array}$ & $\begin{array}{l}3.0 \times 10^{-4} \\
1.7 \times 10^{-4}\end{array}$ & $5.7 \times 10^{-1}$ \\
\hline 4 & A1922 & $\begin{array}{l}\mathrm{A} 1922 \\
\mathrm{~B} 19941 / 75\end{array}$ & $\begin{array}{l}1.7 \times 10^{-2} \\
9.4 \times 10^{-3}\end{array}$ & $5.5 \times 10^{-1}$ \\
\hline
\end{tabular}

\footnotetext{
${ }^{a}$ Short-term DNA exposure technique as previously described (7).

${ }^{\circ}$ Each experiment was performed with identical aliquots of the same recipient population, exposed to the various donor DNAs in parallel.

c T, Transformants; E, colony-forming units exposed to DNA.

${ }^{d}$ Autologous transformation $=$ transformation of the recipient with its own mutant DNA (first line of each experiment).
} 
TABLE 2. Attempts to transform strain A1922 with DNAs from various species of oxidase-positive rods ${ }^{a}$

\begin{tabular}{|c|c|c|c|c|}
\hline \multirow[b]{2}{*}{ Expt no. ${ }^{b}$} & \multirow[b]{2}{*}{ Donor species/strain ${ }^{c}$} & \multicolumn{2}{|c|}{ Transformant yield: } & \multirow{2}{*}{$\begin{array}{l}\text { Ratio of interstrain to } \\
\text { autologous transfor- } \\
\text { mation }\end{array}$} \\
\hline & & $\begin{array}{l}\text { Per } \mathrm{ml} \text { in } 20 \text {-min } \\
\text { DNA exposure }\end{array}$ & $\begin{array}{l}\text { On comparable sur- } \\
\text { face area in long- } \\
\text { term DNA exposure }\end{array}$ & \\
\hline \multirow[t]{2}{*}{4} & Strain A1922 & $3.0 \times 10^{6}$ & Confluent & \\
\hline & $\begin{array}{l}\text { Moraxella phenylpyrouvica } 752 / \\
\quad 52\end{array}$ & $\sim 1.0 \times 10^{1}$ & 27 & $\sim 3.3 . \times .10^{-6 f}$ \\
\hline \multirow[t]{2}{*}{5} & M. phenylpyrouvica $752 / 52$ & & 28 & \\
\hline & $\begin{array}{l}\text { M. phenylpyrouvica 2863, 11865/ } \\
\text { 52, ATCC } 17958\end{array}$ & & $0-3$ & $<10^{-6 g}$ \\
\hline \multirow[t]{8}{*}{6} & M. phenylpyrouvica $752 / 52$ & & 11 & \\
\hline & M. nonliquefaciens $4663 / 62$ & & & \\
\hline & $M$. bovis ATCC 10900 & & & \\
\hline & $M$. lacunata ATCC 11748 & & & \\
\hline & M. osloensis A1920 & & $0-3$ & $<10^{-6 g}$ \\
\hline & $\begin{array}{l}\text { Kingella kingae } 4177 / 66 \\
\text { "M. urethralis" WM20 }\end{array}$ & & $0-0$ & -10 \\
\hline & "New Moraxella" of Bijsterveld & & & \\
\hline & 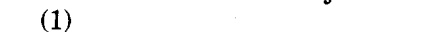 & & & \\
\hline
\end{tabular}

${ }^{a}$ Streptomycin resistance transformation, performed as described (7).

${ }^{b}$ Each experiment was performed with identical aliquots of the recipient, exposed in parallel to different donor DNAs.

'All strains have been employed in previous taxonomic studies $(1,4,5,9,11,14,16,18,19,22)$.

"Technique as described previously (7).

" Autologous transformation = transformation of strain A1922 with its own mutant DNA (experiment no. 4, first line).

${ }^{f}$ Directly calculated from column 3 .

${ }^{g}$ Calculated from the number of transformants in column 4 relative to the number elicited by strain $752 /$ 52.

the strains studied has been described separately (21a).

\section{RESULTS}

Genetic affinities in transformation. Table 1 shows the mutual affinities within the new group of strains. The ratios of interstrain to autologous transformation ranged from $4.7 \times$ $10^{-1}$ to $8.0 \times 10^{-1}$, i.e., from 47 to $80 \%$. These values are uniformly within the limits expected for strains belonging to the same species. For comparison, the ranges found in large groups of $M$. nonliquefaciens and $M$. osloensis strains were 34 to $99 \%$ and 32 to $100 \%$, respectively (2, $3)$.

As shown in Tables 2 and 3, the new genetic entity had no close affiliation to any other recognized species of Moraxella, or to some doubtful associates of that genus. On the other hand, there was some affinity to well-established Moraxella species, such as $M$. nonliquefaciens and $M$. osloensis, with interstrain to autologous transformation reactions at the level of $10^{-5}$ to less than $10^{-6}$, similar to reactions with the "false neisseriae" species Neisseria catarrhalis and Neisseria ovis. (The genus designa- tion Moraxella [17] has been proposed for these organisms, and for one of them, $N$. catarrhalis, the genus name Branhamella has been proposed [13]. While this taxonomic problem is being reexamined, the designation Neisseria is maintained.) These interactions were in the same order of magnitude as that typically found between species in this large genetic group (Table 3 [4]). It is noted that one $M$. phenylpyrouvica strain was able to transform an active recipient of the new entity very weakly. On the other hand, no affinity was found to Neisseria elongata nor to an Acinetobacter strain.

DNA base composition. Table 4 shows that three strains of the new entity had $\mathrm{G}+\mathrm{C}$ values for their DNAs ranging from 46 to $47.5 \mathrm{~mol} \%$. This range is clearly higher than that in strictly compared $M$. phenylpyrouvica and other established Moraxella species and "false neisseriae" (40 to $45 \mathrm{~mol} \%$ ) (5) and close to that of the tentatively named $M$. urethralis (22) and the new Moraxella of Bijsterveld (1).

Cells, colonies, and motility. The five strains of the new species consisted of variably sized, often plump, diplococcobacillary to dis- 
TABLE 3. Transforming effect of DNAs of the new species and reference donors on various recipients of Neisseriaceae ${ }^{a}$

\begin{tabular}{|c|c|c|c|c|}
\hline Expt no." & Recipient species/strain & Donor species/strain ${ }^{c}$ & $\begin{array}{l}\text { Transformants per } \\
\text { plate in long-term } \\
\text { DNA exposure }\end{array}$ & $\begin{array}{l}\text { Ratio of interstrain to autolo- } \\
\text { gous transformation" }\end{array}$ \\
\hline \multirow[t]{2}{*}{8} & \multirow[t]{2}{*}{$\begin{array}{l}\text { Moraxella nonlique- } \\
\text { faciens NCTC } 7784\end{array}$} & $\begin{array}{l}M . \text { osloensis } 5873 \\
\text { M. phenylpyrouvica } 752 / \\
52,2863,11865 / 52 \\
\text { ATCC } 17958\end{array}$ & $\begin{array}{r}76 \\
15-29\end{array}$ & $\begin{array}{l}<10^{-6 i f} \\
<10^{-6, g}\end{array}$ \\
\hline & & $\begin{array}{l}\text { New species, strains } \\
\text { A279, A1922, 5118, } \\
8330\end{array}$ & $23-61$ & $<10^{-6 g}$ \\
\hline \multirow[t]{2}{*}{9} & \multirow[t]{2}{*}{ M. osloensis 5873} & $\begin{array}{l}M . \text { nonliquefaciens } \\
\text { NCTC } 7784\end{array}$ & 161 & \\
\hline & & $\begin{array}{l}\text { New species, strains } \\
\text { A279, A1922, 5118, } \\
8330\end{array}$ & $173-331$ & $6 \times 10^{-6}-6 \times 10^{-5 g}$ \\
\hline \multirow[t]{2}{*}{10} & \multirow{2}{*}{$\begin{array}{l}\text { Neisseria catarrhalis } \\
\quad \mathrm{Ne} 11\end{array}$} & M. bovis ATCC 10900 & 1,600 & $3.7 \times 10^{-5 f}$ \\
\hline & & $\begin{array}{l}\text { M.phenylpyrouvica } 2863 \\
\text { New species, strains } \\
\text { A279, A1922, 5118, } \\
8330\end{array}$ & $\left.\begin{array}{r}326 \\
196-410\end{array}\right\}$ & $5 \times 10^{-6}-9 \times 10^{-6 g}$ \\
\hline \multirow[t]{3}{*}{11} & \multirow[t]{3}{*}{ N. ovis $199 / 55$} & M. osloensis 5873 & 1,300 & $2.7 \times 10^{-5 f}$ \\
\hline & & M.phenylpyrouvica 2863 & $561\}$ & $\sim 10^{-5 g}$ \\
\hline & & $\begin{array}{l}\text { New species, strain } \\
\quad \text { A279 }\end{array}$ & $479\}$ & 10 \\
\hline \multirow[t]{2}{*}{12} & \multirow[t]{2}{*}{ N. elongata M2 } & $\begin{array}{l}N . \text { meningitidis } \\
\mathrm{B} 8152 / 66\end{array}$ & 4,000 & $9.2 \times 10^{-3 f}$ \\
\hline & & $\begin{array}{l}\text { New species, strain } \\
5118\end{array}$ & 0 & $<3 \times 10^{-6 g}$ \\
\hline \multirow[t]{3}{*}{13} & \multirow[t]{3}{*}{$\begin{array}{l}\text { Acinetobacter cal- } \\
\text { coaceticus } \mathrm{Bd} 4\end{array}$} & $\begin{array}{l}\text { Acinetobacter ATCC } \\
\quad 17985\end{array}$ & 3,000 & $9.2 \times 10^{-4 h}$ \\
\hline & & $\begin{array}{l}\text { M. phenylpyrouvica } \\
\text { A390, 752/52, } 2863\end{array}$ & $0-3$ & $<6 \times 10^{-7 g}$ \\
\hline & & $\begin{array}{l}\text { New species, strain } \\
\text { A279 }\end{array}$ & 2 & \\
\hline
\end{tabular}

${ }^{a}$ Streptomycin resistance transformation, performed as described (7).

${ }^{\circ}$ Each experiment was performed with identical aliquots of the recipient, exposed in parallel to the various donor DNAs.

'All heterologous species/strains have been employed in previous taxonomic studies $(4,5,8,9,12,14,20)$. Neisseria catarrhalis and $N$. ovis have alternative designations-Moraxella (17) or Branhamella (13) (see text).

"Technique as described (7).

"Autologous transformation = transformation of the recipient in question by its own mutant DNA.

${ }^{f}$ Reference ratios, based directly or indirectly on quantitative transformation experiments, previous determination $(4,12)$. 4).

"Ratios calculated from reference ratios on the basis of relative value in long-term DNA exposure (column

${ }^{h}$ Reference ratio, based on quantitative transformation experiments in this study (short-term DNA exposure [7]).

tinctly rod-shaped cells (averaging 1.0 by 2.0 $\mu \mathrm{m}$; see below), with little tendency to grow in longer chains. When influenced by penicillin in low concentrations (slightly inhibited growth around penicillin depots on blood agar), they behaved like most other rod-shaped bacteria with constant division plane, with elongation as long threads of somewhat varying dimension, but without formation of fusiform cells as seen in most strains of $M$. osloensis (K. Bøvre, N. Hagen, B. P. Berdal, and E. Jantzen, Acta Pathol. Microbiol. Scand. Sect. B, in press) and sometimes in $M$. phenylpyrouvica (Table 5). The cells were gram negative, with some ten- 
TABLE 4. Determination of DNA base composition of the new species and of Moraxella phenylpyrouvica

\begin{tabular}{|c|c|c|c|c|}
\hline $\operatorname{Expt}^{a}$ & Strain & $\begin{array}{l}\text { Buoyant density }(\rho) \text { in } \mathrm{CsCl} \\
\left(\mathrm{g} / \mathrm{cm}^{3}\right)^{b}\end{array}$ & $\mathbf{M o l} \% \mathbf{G}+\mathbf{C}^{c}$ & $\begin{array}{l}\text { Mol\% } \mathrm{G}+\mathrm{C} \text { in litera- } \\
\text { ture }\end{array}$ \\
\hline $\mathrm{a}$ & $\begin{array}{l}\text { A279 } \\
5118 \\
M . \text { phenylpyrouvica } \\
\quad 11865 / 52\end{array}$ & $\begin{array}{l}1.7065 \\
1.7070 \\
1.7035\end{array}$ & $\begin{array}{l}46.5 \\
47.0 \\
43.5\end{array}$ & $42.5^{d}$ \\
\hline$b$ & $\begin{array}{l}\text { A1922 } \\
5118 \\
\text { M. phenylpyrouvica } \\
\quad 752 / 52\end{array}$ & $\begin{array}{l}1.7060 \\
1.7075 \\
1.7035\end{array}$ & $\begin{array}{l}46.0 \\
47.5 \\
43.5\end{array}$ & $43.5^{p}$ \\
\hline
\end{tabular}

${ }^{a}$ In each experiment DNA extraction and purification were done in parallel, and the buoyant densities were determined in the same analytical centrifuge run (5).

${ }^{b}$ Referred to Escherichia coli K-12 DNA, assumed density $1.710 \mathrm{~g} / \mathrm{cm}^{3}$.

${ }^{c}$ Calculated from the buoyant density, using the simplified formula mol\% $\mathrm{G}+\mathrm{C}=1,000(\rho-1.660)$.

${ }^{d}$ Chemical determination by Catlin and Cunningham (14).

$e$ Buoyant density determination by Bøvre et al. (5).

dency to retain the crystal violet stain. Capsules or poly- $\beta$-hydroxybutyrate inclusions were not formed (Table 5).

The colonies were slightly opaque and of small size on all media (see below and Table 5), generally a little smaller than $M$. phenylpyrouvica colonies. Usually, two main colony variants could be observed in each strain, one hemispherical with even outline (Fig. 1), the other slightly larger, more flat, or with irregular margin, and with a tendency to form a spreading zone (Fig. 2, variants observed in Fig. 1). When the colonies were removed, pitting or corrosion of the agar could be observed, generally more pronounced beneath the latter colony type (Fig. 2). Transition from the former to the latter type often occurred on prolonged serial subculture, even without attempts to select for this type of colony. Thus, the colony type variation may be different from that observed in several Moraxella species, where nonspreading, noncorroding colonies tend to be spontaneously enriched in subculture (6). Exceptional was strain B19941/75, which never showed spreading, thus resembling $M$. phenylpyrouvica (Table 5). The strains with the greatest tendency to form corroding colonies, A1922 and 5118 , were those having the highest competence in genetic transformation (Table 1). To some extent this resembles the association between colony type and competence observed in other species of Moraxella (7). However, stably noncorroding and incompetent variants of these two strains were not observed, so that the association could not be critically tested.

Agar plate microscopy of spreading zones showed cells or small groups of cells scattered on the agar (Fig. 3). Slight movement of occasional cells could be detected. As this was different from swimming and Brownian move- ment and the morphology of the spreading zone seemed typical, the mechanism of spreading was considered likely to be twitching motility (15). No swimming motility could be detected in fluid media or hanging drop preparations.

Electron microscopy. The electron micrograph of Fig. 4 illustrates the size and form variation of the cells in strain A1922. The cells had a convoluted surface. A radiating pattern was typical of the granular zone just outside the cells. In some cases (not shown), this could extend $1 \mu \mathrm{m}$ from the cells and seemed to contain thin fimbriae. Typical fimbriae of 6- to 8$\mathrm{nm}$ width were found associated with 25 to $100 \%$ of the cells, there being one to four per cell. Their length varied from 0.5 to several micrometers. They were mostly single and straight or slightly curved, and were found in relation to all parts of the cell surface, but possibly with some preference for the end regions. All colony variants studied had fimbriae, and no clear difference was apparent in number or pattern for hemispherical and flat colonies (see above). Cell wall protrusions were present to a varying extent on most of the cells.

Biochemical reactions and growth. The oxidase (both methods of reference 10) and catalase reactions were uniformly strongly positive. There was no pigment production or hemolysis (only human blood tested), except that in old blood agar cultures the colonies appeared slightly pink and the medium often showed a slight greenish discoloration. No discoloration of heated blood agar was observed. All strains grew in nutrient broth and on agar media without serum, including Hugh and Leifson $\mathrm{O} / \mathrm{F}$ medium (distinct fine growth along the stab in three passages) and tryptose blood agar base (Oxoid). Growth was not clearly improved by blood, heated blood, serum, or $\mathrm{CO}_{2}$. Only occa- 
TABLE 5. Some morphological and cultural-biochemical characteristics of strains belonging to the new species and to Moraxella phenylpyrouvica ${ }^{a}$

\begin{tabular}{|c|c|c|c|c|}
\hline \multirow{2}{*}{ Test, character } & \multicolumn{2}{|c|}{ New species (5 strains) } & \multicolumn{2}{|c|}{ M. phenylpyrouvica (11 strains) } \\
\hline & Typical & Deviating (strains) & Typical & Deviating (strains) \\
\hline $\begin{array}{l}\text { Fusiform cells with } \\
\text { penicillin }\end{array}$ & - & & - & $\begin{array}{l}\text { w(A390, } \\
\quad 752 / 52,5542) \\
\quad+(9158)\end{array}$ \\
\hline $\begin{array}{l}\text { Poly- } \beta \text {-hydroxybutyr- } \\
\text { ate inclusions }\end{array}$ & - & & - & $\mathrm{w}(2863)$ \\
\hline $\begin{array}{l}\text { Colony diameter, } \\
20 \mathrm{~h}(\mathrm{~mm})^{b}\end{array}$ & $0.1-0.3$ & $0.5(\mathrm{~A} 1922)$ & $0.4-0.5$ & \\
\hline $\begin{array}{l}\text { Colony diameter, } \\
48 \mathrm{~h}(\mathrm{~mm})^{b}\end{array}$ & $0.2-0.5$ & $1.0(\mathrm{~A} 1922)$ & $0.9-1.0$ & \\
\hline Agar corrosion, pitting ${ }^{b}$ & w & $+(\mathrm{A} 1922,5118)$ & - & $\mathrm{w}(752 / 52)$ \\
\hline $\begin{array}{l}\text { Colony spreading } \\
\text { observed }\end{array}$ & + & $-(\mathrm{B} 19941 / 75)$ & - & \\
\hline $\begin{array}{l}\text { Peptone water, } 1 \% \\
\text { (wt/vol), growth }\end{array}$ & w & $+(\mathrm{A} 1922,5118)$ & + & \\
\hline Koser citrate, growth & - & $\mathrm{w}(8330)$ & - & $+(2863)$ \\
\hline $\begin{array}{l}\text { Hutner medium with } \\
\text { acetate, growth }\end{array}$ & - & $\mathrm{w}(\mathrm{B} 19941 / 75)$ & - & $+(2863)$ \\
\hline Growth at $4^{\circ} \mathrm{C}^{b}$ & - & & $\mathrm{w}(6-14$ days $)$ & \\
\hline Growth at $10^{\circ} \mathrm{C}^{b}$ & - & & $w(4-5$ days $)$ & \\
\hline Growth at $22^{\circ} \mathrm{C}^{b}$ & $\mathrm{w}(4 \text { days })^{r}$ & & $+(1$ day $)$ & \\
\hline Survival at $4^{\circ} \mathrm{C}^{b}$ & 1-2 weeks & 4-6 weeks(A279, 8330) & 16 weeks & \\
\hline Survival at $33^{\circ} \mathrm{C}^{b}$ & $6-16$ weeks & 2 weeks $(5118)$ & 16 weeks & \\
\hline $\begin{array}{l}\text { Nitrate, reduction to } \\
\text { nitrite }\end{array}$ & - & & + & $-(2863), \mathrm{w}(240,9413)$ \\
\hline Urease production & - & & + & $\begin{array}{l}-(11865 / 52, \text { ATCC } \\
17958)\end{array}$ \\
\hline $\begin{array}{l}\text { Phenylalanine/trypto- } \\
\text { phan deaminase }\end{array}$ & - & & + & \\
\hline $\begin{array}{l}\text { Benzylpenicillin, } \\
\text { MIC }(\mathrm{U} / \mathrm{ml})^{\prime}\end{array}$ & 0.1 & $0.05(\mathrm{~A} 1922)$ & $0.01-0.025$ & $\begin{array}{l}0.05(240, \text { A } 390 \\
\quad \text { A } 1019,5542,9413)\end{array}$ \\
\hline $\mathrm{NaCl}, \mathrm{MIC}(\mathrm{g} / 100 \mathrm{ml})^{b}$ & 3 & & 9 & $7.5(5542), 4.5(1232)$ \\
\hline $\begin{array}{l}\text { Bile salts, }{ }^{d} \text { growth } \\
\text { stimulated by concen- } \\
\text { trations }(\mathrm{g} / 100 \mathrm{ml})\end{array}$ & $0.2-1^{f}$ & & $0.05-4^{f}$ & \\
\hline $\begin{array}{l}\text { Bile salts, }{ }^{d} \text { MIC } \\
(\mathrm{g} / 100 \mathrm{ml})\end{array}$ & 3 & & 5 & \\
\hline
\end{tabular}

${ }^{a}$ Procedures as described in ref. 10 and in text. Other results not tabulated: all strains of the two species were oxidase and catalase positive, grew on Hugh and Leifson $\mathrm{O} / \mathrm{F}$ medium, did not grow at $42^{\circ} \mathrm{C}$ or anaerobically, were nonhemolytic and did not produce acid from carbohydrates, and did not reduce nitrite, liquefy serum or gelatin, or produce indole or $\mathrm{H}_{2} \mathrm{~S}$; for further characteristics, see text.

${ }_{b}^{b}$ Blood agar (6), humid atmosphere.

c $\mathrm{MIC}=$ minimal inhibitory concentration, determined by dilution in solid medium (heated blood agar).

"Bile salts (oxoid, code L55) incorporated in tryptose blood agar base (Oxoid).

' $\mathrm{w}$, Weak growth or reaction. Time in parentheses indicates delay before distinct growth.

${ }^{f}$ All strains were stimulated by all concentrations within the range.

sionally was growth improved by a humid atmosphere. No growth occurred anaerobically $\left(\mathrm{H}_{2}+\mathrm{CO}_{2}\right)$ or at $42^{\circ} \mathrm{C}$ (solid and fluid media). Optimum temperature for growth was 33 to $37^{\circ} \mathrm{C}$. There was no acid production from glucose or other carbohydrates (as mentioned in reference 10). Nitrite was not reduced. Coagulated serum and gelatin were not liquefied, and indole or $\mathrm{H}_{2} \mathrm{~S}$ was not produced. All these reactions and growth results were shared by the strains of the new species and all of 11 simulta- neously examined strains of $M$. phenylpyrouvica (see Materials and Methods). It should be noted that these results with $M$. phenylpyrouvica differ distinctly from some reactions reported by Snell et al. (23). Snell et al. could not detect growth in Hugh and Leifson medium, and recorded growth anaerobically. They also found that $M$. phenylpyrouvica grew at $42^{\circ} \mathrm{C}$.

Table 5 shows the results of other tests with all 16 strains of the two species. Some traits appeared distinctive between the two, but in 
several cases overlaps and weak reactions disturbed the distinction. The new species appeared to lack the ability of all $M$. phenylpyrouvica strains to grow on solid medium at $4^{\circ}$ to $10^{\circ} \mathrm{C}(23)$. However, the growth of $M$. phenylpyrouvica was slow at these temperatures, and in fluid medium growth also occurred from the strains A279, 8330, and B19941/75 of the new species (not tabulated). The new species was also less tolerant than $M$. phenylpyrouvica to
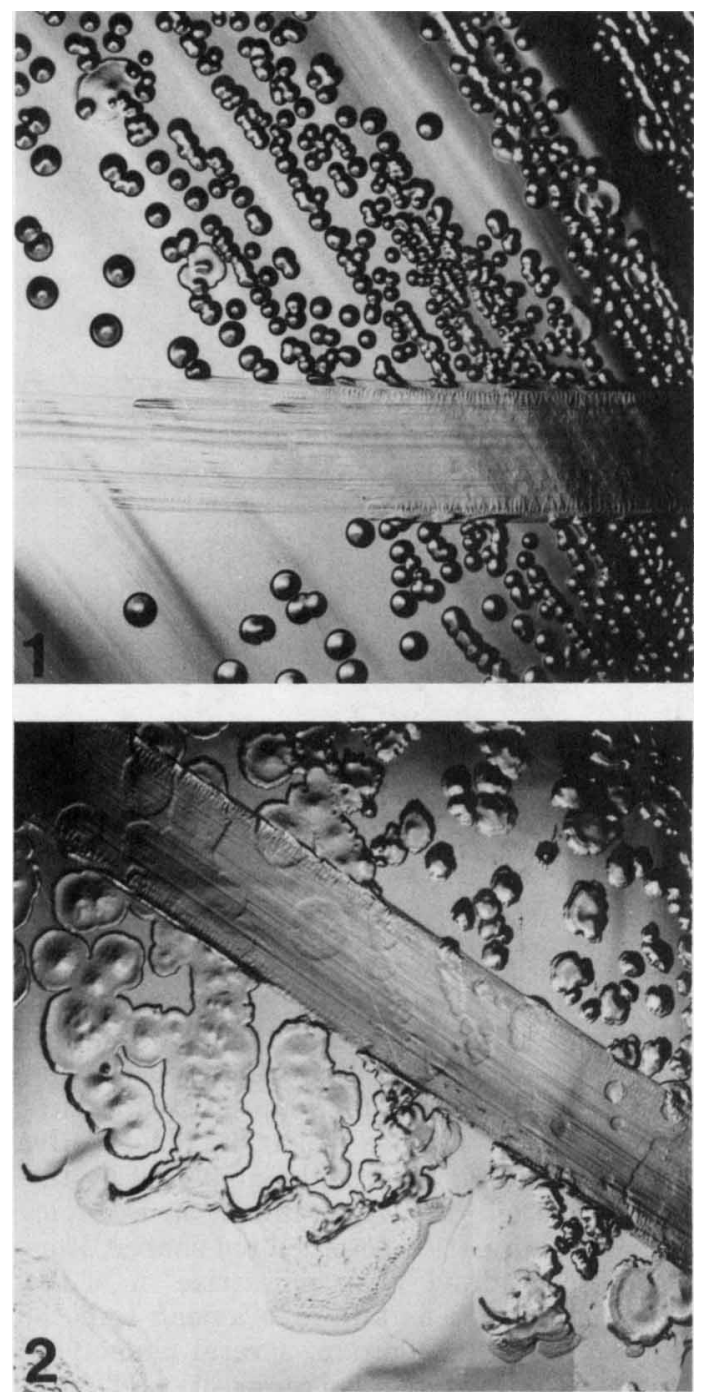

FIG. 1. Strain A1922. Weakly corroding, hemispherical to conical colonies with flat variants on blood agar incubated for 2 days. Magnification, $\times 3.7$.

FIG. 2. Strain A1922. Corroding, mainly flat and partly spreading colonies on blood agar incubated for 2 days. Magnification, $\times 3.7$.

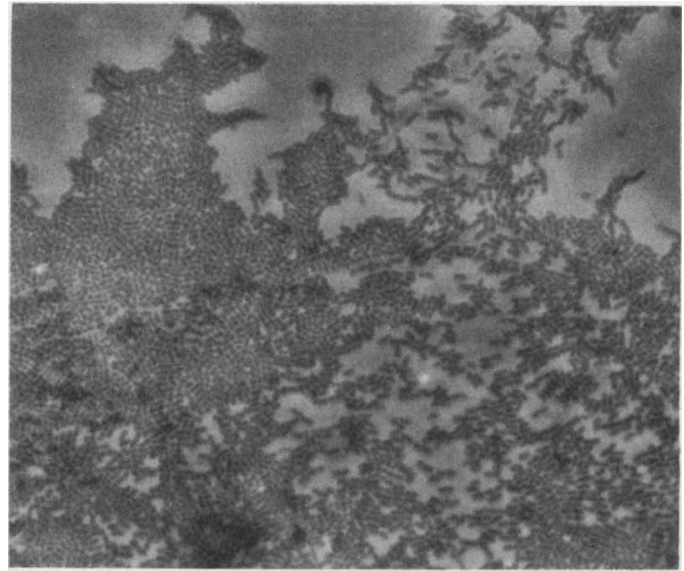

FIG. 3. Strain A1922. Margin of spreading colony on tryptose blood agar base (Oxoid), incubated for 1 day. Magnification, $\times 255$.

sodium chloride (minimal inhibitory concentration $3 \%$ versus 4.5 to $9 \%$ ). Likewise, the behavior on bile salt-containing media appeared to be distinguishing. It is of importance to note that the new species, like $M$. phenylpyrouvica (23), was stimulated by bile. However, the stimulation took place up to a higher concentration of bile salts in $M$. phenylpyrouvica (up to $4 \%$ versus $1 \%$ for the new species). When stimulated, the colonies of $M$. phenylpyrouvica usually attained a much greater size than did colonies of the new species. The minimal concentration of bile salts inhibiting growth was invariably higher in $M$. phenylpyrouvica, but this difference was also rather small ( $5 \%$ versus $3 \%$ ), particularly for comparison between results obtained in different laboratories. Finally, all strains of the new species were phenylalanine and tryptophan deaminase negative, whereas all $M$. phenylpyrouvica strains here examined were positive (see Discussion).

Fatty acid and alcohol content. Table 6 presents the fatty acid and alcohol composition of whole cells of the new species. The similarity of the five strains was striking, and confirmed the genetic finding of a very homogeneous taxonomic entity. All the 14 compounds detected were found in genus Moraxella previously (19). Included in Table 6 are the corresponding values for the 11 strains of $M$. phenylpyrouvica. This species was very homogeneous in these terms, and the similarity between the two species was very high, as the relative amounts of 13 out of 15 compounds (3-OH-16:0, absent in both species, included) overlapped. One fatty acid (16:1) was consistently lower in the new species, but the most clearly distinguishing 


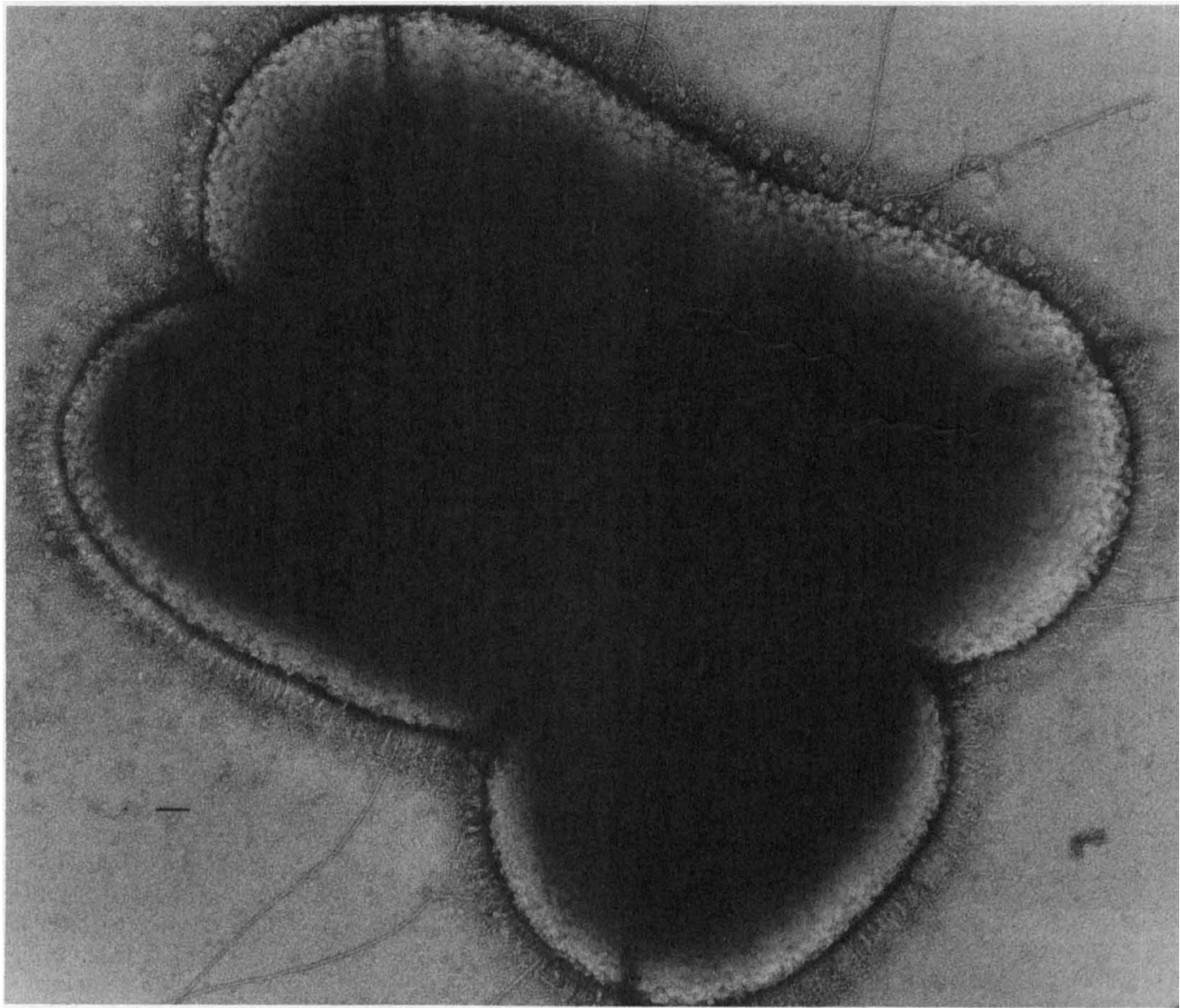

FIG. 4. Strain A1922. Cells from flat colony type (Fig. 2) on blood agar incubated for 11 h. Electron microscopy by negative staining. Magnification, $\times 40,000$. Bar represents $0.1 \mu \mathrm{m}$.

component was the fatty alcohol $n$-octadecanol (18:0alc), which was consistently absent in $M$. phenylpyrouvica. The alcohol was identical to the previously unidentified compound x-5 (19) and was recently shown to be a wax ester constituent (K. Bryn, E. Jantzen, and K. Bøvre, unpublished data). The two strains A1922 and 9413 , one of each species, illustrate the similarity in fatty acid composition between the two entities. As seen from the calculation ("score") presented in Table 6, no precise allocation to species could be performed if the fatty alcohol was excluded from the comparison.

Monosaccharide composition. Gas chromatographic and other chromatographic studies of monosaccharide composition disclosed the presence of mannose in all five strains of the new species and its absence in all of the 11 strains of $M$. phenylpyrouvica and other rodshaped Moraxella species simultaneously examined (21a).

\section{DISCUSSION}

The data on genetic transformation and DNA base composition show that the strains A279, A1922, 8330, and B19941/75 represent one homogeneous and separate group satisfying criteria of a species (Tables 1 to 4 ). Its place in the genus Moraxella is strongly supported by the transformation data. The affinity in heterologous transformation to other rod-shaped Moraxella species and "false neisseriae" is of the same magnitude as affinities among some of the latter (4). In addition, several phenotypic traits, including fatty acid composition (Table 6 $[19,20])$, confirm this allocation to genus.

Phenotypically, the new species most closely resembles $M$. phenylpyrouvica. They are both characterized by small colonies, which do not increase significantly in size on serum media or heated blood agar, and share several other properties in conventional tests (Results; Table 


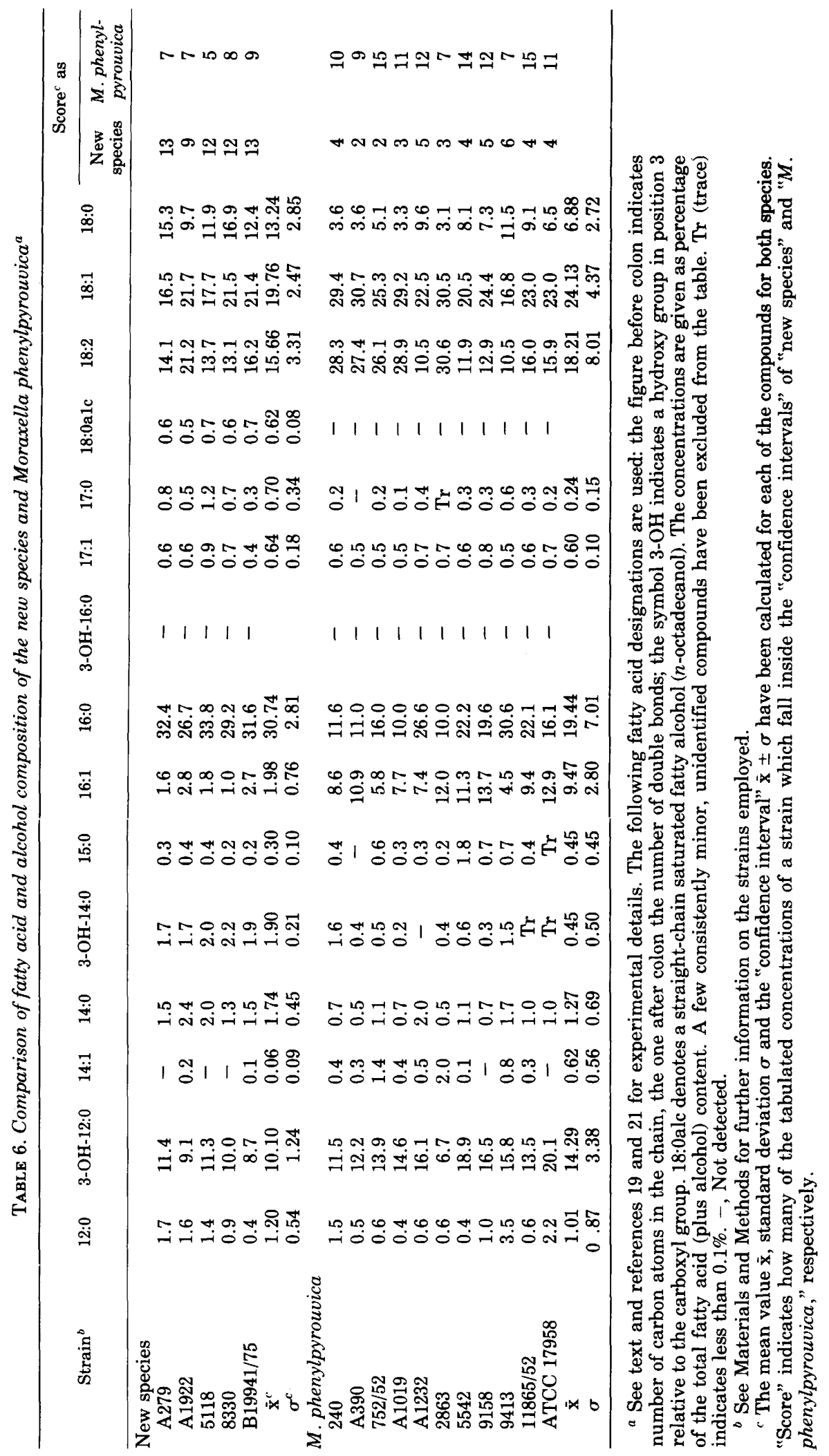


5). Furthermore, the two species are particularly similar in fatty acid composition (Table 6). However, a close comparison between the new species and $M$. phenylpyrouvica reveals several more or less clearly distinguishing hallmarks. The inability of the new species to grow on solid medium at 4 to $10^{\circ} \mathrm{C}$, and at 33 to $37^{\circ} \mathrm{C}$, to grow well with $3 \%$ sodium chloride or $3 \%$ bile salts in the medium, appears distinct from $M$. phenylpyrouvica. The differences between the two in these respects are not pronounced, however, so that direct comparisons with several controls may be necessary for the use of these characteristics in identification. The tendency of the new species to form corroding and/or spreading colony variants may also be used for a tentative diagnosis. Phenylalanine and tryptophan deaminase activities were consistently absent in the new species. However, these activities have also been found missing or very weak in some recently isolated $M$. phenylpyrouvica strains (Bøvre et al., in press), rendering the tests somewhat questionable for the distinction. Finally, the new species can be distinguished from $M$. phenylpyrouvica by its cellular content of the fatty alcohol $n$-octadecanol, and mannose, detectable by gas chromatography.

The ability of the new species to grow on Hugh and Leifson O/F medium, its negative nitrate reaction, its relatively low sensitivity to penicillin (Table 5), and the mentioned points of similarity to $M$. phenylpyrouvica may serve to distinguish it from $M$. nonliquefaciens (2). Key phenotypic traits of $M$. osloensis, although somewhat variable (Bøvre et al., in press), should make the distinction from that species relatively easy. However, as more strains are examined of the new species and of related species, ranges of phenotypic variation are expected to increase. In selected cases of identification it may therefore be important to utilize the systems of genetic transformation and gas chromatographic analysis developed for these microorganisms.

We propose the name Moraxella atlantae for the new species recognizing the pioneer work of the late Elizabeth $\mathrm{O}$. King of Atlanta, Ga. The strain 5118 is proposed as the type strain. The strain A1922 may be a useful reference strain, due to its high transformability. All five strains have been deposited in the American Type Culture Collection and in the National Collection of Type Cultures (Great Britain).

\section{Condensed Description of Moraxella atlantae sp. nov.}

Cellular morphology. Variably sized, often plump, diplococcobacillary to distinctly rodshaped cells (average 1.0 by $2.0 \mu \mathrm{m}$ ), with little tendency to grow in longer chains. Often fimbriated. Gram negative, with some tendency to resist decolorization. Not encapsulated. Does not form poly- $\beta$-hydroxybutyrate inclusions.

Colony morphology. Slightly opaque, small colonies on all media (diameter on blood agar most often 0.1 to $0.3 \mathrm{~mm}$ after incubation for 20 h). Two main colony variants, one hemispherical with an even outline, the other more flat or with irregular margin, and with a tendency to form a spreading zone. Pitting of the agar, more pronounced beneath the latter colony variant.

Motility. No swimming motility. May show twitching.

Oxidase and catalase reactions. Strongly positive.

Pigment production and hemolysis. None.

Culture medium, growth stimulation and tolerance. Grows with low cell yield in nutrient broth and on agar media without serum, including Hugh and Leifson O/F medium. No significant stimulation by serum or heated blood. Weak growth in peptone water, and usually no growth in Koser citrate and Hutner medium with acetate. Stimulated by bile salts up to $1 \mathrm{~g} / 100 \mathrm{ml}$. Minimal inhibitory concentration of bile $-3 \mathrm{~g} / 100 \mathrm{ml}$; of sodium chloride -3 $\mathrm{g} / 100 \mathrm{ml}$, all in solid medium.

Atmosphere. Strict aerobe, not distinctly stimulated by $\mathrm{CO}_{2}$ or humidity.

Temperature. No growth on solid medium at 4 to $10^{\circ} \mathrm{C}$, slight growth at $22^{\circ} \mathrm{C}$, optimum temperature for growth 33 to $37^{\circ} \mathrm{C}$, no growth at $42^{\circ} \mathrm{C}$.

Survival. Blood agar cultures remain viable for 1 to 6 weeks at $4^{\circ} \mathrm{C}$ and for 2 to 16 weeks at $33^{\circ} \mathrm{C}$ (humid atmosphere).

Carbohydrates. No acid production.

Nitrate and nitrite reduction. Negative.

Proteolytic enzymes. Coagulated serum and gelatin are not liquefied, and indole or $\mathrm{H}_{2} \mathrm{~S}$ are not produced. Urease, phenylalanine deaminase, and tryptophan deaminase reactions are negative.

Sensitivity to penicillin. Minimal inhibitory concentration 0.05 to $0.1 \mathrm{U} / \mathrm{ml}$.

Fatty acid, alcohol, and monosaccharide composition. Fatty acid pattern similar to that of $M$. phenylpyrouvica, but differs from that species in containing the fatty alcohol $n$-octadecanol. Distinguishable from other rod-shaped Moraxella species by its cellular content of mannose.

DNA base composition. 46 to $47.5 \mathrm{~mol} \%$ $\mathrm{G}+\mathrm{C}$.

Genetic affinities. Often transformable. No transformation (streptomycin resistance marker) detected with DNA from $M$. nonlique- 
faciens, M. lacunata, M. bovis, M. osloensis, or Kingella kingae. Marginal transformation with $M$. phenylpyrouvica DNA. Low, but distinct donor activity in transformation of recipients of $M$. nonliquefaciens, $M$. osloensis, and Neisseria (Moraxella, Branhamella) catarrhalis and ovis $\left(10^{-5}\right.$ to less than $10^{-6}$, interstrain to autologous transformation). No affinity to $N$. elongata or Acinetobacter.

\section{ACKNOWLEDGMENTS}

This study was supported by the Norwegian Research Council for Science and the Humanities, grants C.07.01-1 (to K.B.) and C.00.01-10 (to J.E.F.)

\section{REPRINT REQUESTS}

Address reprint requests to Professor K. Bøvre, Department of Microbiology, University Hospital, 9012 Tromsø, Norway.

\section{LITERATURE CITED}

1. Bijsterveld, O. P. van. 1970. New Moraxella strain isolated from angular conjunctivitis. Appl. Microbiol. 20:405-407.

2. Bøvre, K. 1964. Studies on transformation in Moraxella and organisms assumed to be related to Moraxella. 2. Quantitative transformation reactions between Moraxella nonliquefaciens strains, with streptomycin resistance marked DNA. Acta Pathol. Microbiol. Scand. 62:239-248.

3. Bøvre, K. 1965. Studies on transformation in Moraxella and organisms assumed to be related to Moraxella. 6 . A distinct group of Moraxella nonliquefaciens-like organisms (the "19116/51" group). Acta Pathol. Microbiol. Scand. 65:641-652.

4. Bøvre, K. 1967. Studies on transformation in Moraxella and organisms assumed to be related to Moraxella. 7 . Affinities between oxidase positive rods and neisseriae, as compared with group interactions on both sides. Acta Pathol. Microbiol. Scand. 69:92-108.

5. Bøvre, K., M. Fiandt, and W. Szybalski. 1969. DNA base composition of Neisseria, Moraxella, and Acinetobacter, as determined by measurement of buoyant density in $\mathrm{CsCl}$ gradients. Can. J. Microbiol. 15:335338.

6. Bøvre, K., and L. O. Frøholm. 1972. Variation of colony morphology reflecting fimbriation in Moraxella bovis and two reference strains of $M$. nonliquefaciens. Acta Pathol. Microbiol. Scand. Sect. B 80:629-640.

7. Bøvre, K., and L. O. Frøholm. 1972. Competence in genetic transformation related to colony type and fimbriation in three species of Moraxella. Acta Pathol. Microbiol. Scand. Sect. B 80:649-659.

8. Bovre, K., and S. D. Henriksen. 1967. A new Moraxella species, Moraxella osloensis, and a revised description of Moraxella nonliquefaciens. Int. J. Syst. Bacteriol. 17:127-135.

9. Bøvre, K., and S. D. Henriksen. 1967. A revised description of Moraxella polymorpha Flamm 1957, with a proposal of a new name, Moraxella phenylpyrouvica, for this species. Int. J. Syst. Bacteriol. 26:92-96.

10. Bøvre, K., and S. D. Henriksen. 1976. Minimal standards for description of new taxa within the genera
Moraxella and Acinetobacter: proposal by the Subcommittee on Moraxella and Allied Bacteria. Int. J. Syst. Bacteriol. 26:92-96.

11. Bøvre, K., S. D. Henriksen, and V. Jonsson. 1974. Correction of the specific epithet kingii in the combinations Moraxella kingii Henriksen and Bøvre 1968 and Pseudomonas kingii Jonsson 1970 to kingae. Int. J. Syst. Bacteriol. 24:307.

12. Bøvre, K., and E. Holten. 1970. Neisseria elongata sp. nov., a rodshaped member of the genus Neisseria. Reevaluation of cell shape as a criterion in classification. J. Gen. Microbiol. 60:67-75.

13. Catlin, B. W. 1970. Transfer of the organism named Neisseria catarrhalis to Branhamella gen. nov. Int. J. Syst. Bacteriol. 20:149-150.

14. Catlin, B. W., and L. S. Cunningham. 1964. Transforming activities and base composition of deoxyribonucleases from strains of Moraxella and Mima. J. Gen. Microbiol. 37:353-367.

15. Henrichsen, J., L. O. Frøholm, and K. Bøvre. 1972. Studies on bacterial surface translocation. 2. Correlation of twitching motility and fimbriation in colony variants of Moraxella nonliquefaciens, $M$. bovis and $M$. kingii. Acta Pathol. Microbiol. Scand. Sect. B 80:445-452.

16. Henriksen, S. D., and K. Bovre. 1968. Moraxella kingii sp. nov., a haemolytic, saccharolytic species of the genus Moraxella. J. Gen. Microbiol. 51:377-385.

17. Henriksen, S. D., and K. Bøvre. 1968. The taxonomy of the genera Moraxella and Neisseria. J. Gen. Microbiol. 51:387-392.

18. Henriksen, S. D., and K. Bøvre. 1976. Transfer of Moraxella kingae Henriksen and Bøvre to the genus Kingella gen. nov. in the family Neisseriaceae. Int. J. Syst. Bacteriol. 26:447-450.

19. Jantzen, E., K. Bryn, T. Bergan, and K. Bøvre. 1974. Gas chromatography of bacterial whole cell methanolysates. V. Fatty acid composition of neisseriae and moraxellae. Acta Pathol. Microbiol. Scand. Sect. B 82:767-779.

20. Jantzen, E., K. Bryn, T. Bergan, and K. Bovre. 1975. Gas chromatography of bacterial whole cell methanolysates. VII. Fatty acid composition of Acinetobacter in relation to the taxonomy of Neisseriaceae. Acta Pathol. Microbiol. Scand. Sect. B 83:569-580.

21. Jantzen, E., K. Bryn, and K. Bøvre. 1974. Gas chromatography of bacterial whole cell methanolysates. IV: A procedure for fractionation and identification of fatty acids and monosaccharides of cellular structures. Acta Pathol. Microbiol. Scand. Sect. B 82:753766 .

21a. Jantzen, E., K. Byrn, and K. Bovre. 1976. Cellular monosaccharide patterns of Neisseriaceae. Acta $\mathrm{Pa}$ thol. Microbiol. Sect. B 84:177-188.

22. Lautrop, H., K. Bøvre, and W. Frederiksen. 1970. A Moraxella-like microorganism isolated from the genito-urinary tract of man. Acta Pathol. Microbiol. Scand. Sect. B 78:255-256.

23. Snell, J. J. S., L. R. Hill, and S. P. Lapage. 1972. Identification and characterization of Moraxella phenylpyruvica. J. Clin. Pathol. 25:959-965.

24. Tatum, H. W., W. H. Ewing, and R. E. Weaver. 1974. Miscellaneous gram-negative bacteria, p. 270-294. In E. H. Lennette, E. H. Spaulding, and J. P. Truant (ed.), Manual of clinical microbiology, 2nd ed. American Society for Microbiology, Washington D.C. 